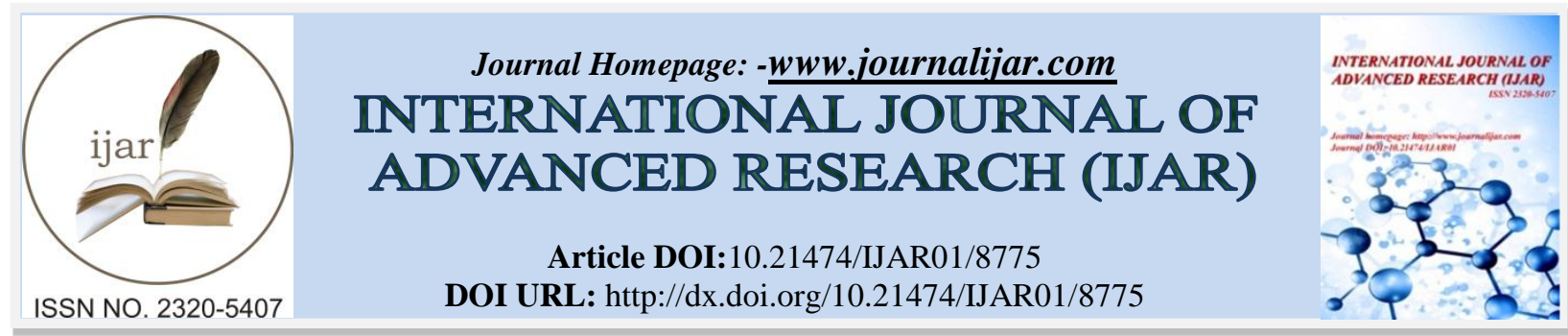

RESEARCH ARTICLE

\title{
EFFECT OF GIRLS' ATTITUDE TOWARDS THE LEARNING AND PERFORMANCE IN CHEMISTRY IN PUBLIC SECONDARY SCHOOLS IN NANDI NORTH SUB-COUNTY, KENYA.
}

\author{
Bitok Norah Jelimo, Prof. Lusweti Kituyi and Dr. Waswa Peter.
}

University of Eldoret, Kenya.

\section{Manuscript Info}

\section{Manuscript History}

Received: 20 January 2019

Final Accepted: 22 February 2019

Published: March 2019

Key words:-

Girls, Attitude, Performance, Chemistry

Secondary Schools .

\begin{abstract}
Chemistry is one of the most important branches of science and its contributions to development of a country need to be emphasized. Its performance, however, has been poor especially amongst girls. The purpose of this study was to determine the effect of girls' attitude towards the performance of girls in chemistry in secondary schools in Nandi North Sub-County, Nandi County, Kenya. Descriptive survey research design was adopted. The sample consisted of 303 Form three students and 9 chemistry teachers selected using proportionate, simple random and purposive sampling techniques. Questionnaires, interviews and observation schedules were used to collect data. Validity and reliability of these instruments were determined before data collection. Quantitative data were analyzed using frequencies, percentages and $\mathrm{t}-$ test while qualitative data were transcribed and arranged thematically before reporting in narrations and quotations. The study found out that there was a significant difference between boys and girls in terms of attitude towards Chemistry. The study recommended that teachers of chemistry need to encourage and motivate girls to develop a positive attitude toward the importance of chemistry as a subject. The findings of this study could provide a framework for teachers on which they could re-evaluate their instructional strategies during chemistry lessons for the enhancement of effective teaching and learning. It could also provide insight for the curriculum designers into the kind of practical experiences in secondary school chemistry needed to aid sound understanding of scientific concepts and principles.
\end{abstract}

Copy Right, IJAR, 2019,. All rights reserved.

\section{Introduction:-}

Chemistry as a subject is universally accepted and realized not only by students but also people who are keen to know about chemicals. The subject provides broader knowledge about science in general which is compulsory to every individual that aims at studying the environment or climate change related courses and medicine. With regard to the causes that contribute to student's performance, several studies have been conducted with regard to school performance in general. Researchers have shown that environmental, parental and family chores have adverse effect on learners' performance (Kalu \& Ali, 2004; Ajayi, Adewale, \& Muraina, 2006). They have also established that educational and occupational status of home and teacher's interest in teaching are some of the factors that affect achievements. Other factors include student's attitude towards science and teachers' home work load. The study also

Corresponding Author:-Bitok Norah Jelimo.

Address:-University of Eldoret, Kenya. 
found that home location, for example, urban or rural has no effect on students' achievement. Some studies have emphasized that home background factors were more important than those in schools in determining students' performance (Hayden \& Thompson, 2005).

Performance in sciences and chemistry in particular has occupied the centre stage in research for a long time. Although focus has been mainly on differential performance of girls and boys, the high volume of this research had been necessitated by the apparent low performance by students in science compared to other subjects. Chemistry took the bottom positions of 13out of 15 subjects and 14 out of 16 subjects in 2012 and 2013 respectively. Performance in Chemistry has declined from 4.2973 to 3.9573 between the years 2012 and 2013. The performance, though was not good at first continues to deteriorate and this is worrying. Sub average performance in Chemistry affects the Sub County's ability to admit students in universities in courses to do with science and technology. In the county, most of the students take Chemistry and therefore poor performance in the subject affects their social mobility. This is despite the fact that the government has put in measures to improve performance in the subject through launching the Strengthening of Mathematics and Science in Secondary Education (SMASSE), in 1998 that aims at improving mathematics and science education through In- Service Training (INSET) for teachers. The study therefore investigated the effect of girls' attitude towards chemistry in public secondary schools in Nandi North SubCounty, Nandi County, Kenya.

\section{Literature Review}

Attitude is defined by Abudu and Gbadamosi (2014) as an idea or thought that is based on a certain situation, which can indicate a person's like or dislike of an item. They furthermore identify attitude in three categories which are positive, negative and neutral. Their research regards attitude towards science as an important factor that affects the students' performances and conceptions about the subject. It is only a positive attitude that can result in a learner doing well in science, because a positive attitude leads to interest in the subject, and interest leads to commitment, and commitment, in turn, leads to a yearning for academic achievement. Their research in the UK indicates that learners enrolling for science in high schools imply that their attitudes towards science are positive. However, the de-contextualized nature of the school science curriculum results in learners having a negative attitude towards school science.

According to Glasman and Albarracín (2006), attitudes predict behaviours. Kelly (1988) found that British students' liking for a particular science subject was a good predictor of their actual choice of physics, chemistry, or biology in schools. Furthermore, research has revealed that students show different attitudes to physics, chemistry, and biology in school (Barnes et al. 2005; Murphy and Whitelegg 2006; Osborne and Collins 2001; Spaull etal. 2013)..Girls tend to respond more positively to biological sciences than to physical sciences (Warrington \& Younger 2000).

Salta and Tzougraki (2003), for example, surveyed 576 high school students in Greece using an attitude scale with four subscales: the difficulty of chemistry course; the interest of chemistry course; the usefulness of chemistry course for students' future career; and the importance of chemistry for students' life. They found no gender differences in student attitudes regarding interest, usefulness, and importance of chemistry, but the interaction effect of gender and grade was not examined.

Chang, Yeung and Cheng (2009) studied ninth graders' learning interests, life experiences and attitudes towards science and technology. A total of 942 urban ninth graders in Taiwan were involved in the study. Pearson correlation was used for data analysis. The results indicated that boys showed higher learning interests in sustainability issues and scientific topics than girls. However, girls recalled more life experiences about science and technology than boys. The results also showed that there was high correlation between learning interests and life experiences related to science and technology, and in the perspective on attitudes towards technology.

Researches focused on gender studies have indicated that attitudes toward science education differ between males and females. A declining interest in Chemistry and the under representation of females in the chemical science was found (Jacobs, 2005; cited in Banye, 2005). Self-confidence toward Chemistry, the influence of role models, and knowledge about the usefulness of chemistry affect the decision of young female students about the study of chemistry (Banye, 2005). In the event of young female students finding difficulty in constructing knowledge of chemistry, self-confidence is lowered with subsequent alternation of attitudes toward chemistry. Despite the studies done, and the recommendations made, the attitudes of young female students toward science and chemistry are still more negative than positive. This study therefore investigated the attitude of girls towards Chemistry subject in secondary schools in Nandi North Sub-County, Kenya. 


\section{Methodology:-}

The study was carried out among students and Chemistry teachers of selected secondary schools in Nandi North Sub-County, Nandi County, Kenya. This study adopted the use of descriptive survey design. Descriptive survey design enabled description of the state of affairs as they were and the findings reported (Kombo \& Tromp, 2009). Further the study adopted the use of mixed methodology where both quantitative and qualitative data collection and analysis approaches were used. According to Creswell and Clark, (2011) the mixing of quantitative and qualitative approaches provides a better understanding of research problems than either approach alone.

The target population consisted of 42 Form three Chemistry teachers and 1563 students. The sample size for this study was determined using sample size determination formula advanced by Krejcie and Morgan (1970) as quoted by Kasomo (2001). The formula is given as:

$$
\mathrm{n}=\frac{X^{2} * N * P(1-P)}{\left(M E^{2} *(N-1)\right)+\left(X^{2} * P *(1-P)\right)}
$$

Where:

$\mathrm{n}=$ Sample size

$\mathrm{X}^{2}=$ Chi-square for the specified confidence level at 1 degree of freedom

$\mathrm{N}=$ population size

$\mathrm{P}=$ population proportion

$\mathrm{ME}=$ Desired Margin of Error (expressed as a proportion)

Using the formula, the sample size for a target of 1563 students at a confidence level of $95 \%$ was 303 students. From a target population of 42 teachers of chemistry, thirty percent (30\%) were selected by simple random sampling technique to get a sample size of 13 teachers. The choice of $30 \%$ is based on the recommendation by Mugenda and Mugenda (2003).

In selecting students to participate in the study; secondary schools were stratified by gender into; single gender and mixed schools. After stratification, 303 students were selected by simple random sampling technique in relation to the population size in each school. The main data collection instruments were questionnaires for students, interviews for teachers and observation schedule. Validity and reliability of the research instruments were tested before using the instruments for collecting data. Data collected for this study were analyzed using both descriptive and inferential statistics. The questionnaire had a four-point scale questions and was scored as: Strongly Disagree $(\mathrm{SD})=1$; Disagree $(D)=2$; Agree $(A)=3$ while Strongly Agree $(S A)=4$. Frequency counts and percentages were used to analyze the data. Qualitative data from the interviews and observations made were thematically classified and arranged before they were reported in narrations and quotations as per the research objectives.

\section{Results:-}

The aim of this study was to investigate the attitude of girls towards learning of Chemistry. To achieve this objective, students were asked to rate their level of agreement on a three-point Likert scale items in the questionnaire on the attitude towards learning of chemistry. Their responses were tabulated and the results presented in Table 1.

Table 1:-Effect of Attitude towards Students' Learning of Chemistry

\begin{tabular}{|c|c|c|c|c|c|c|c|}
\hline \multirow[t]{2}{*}{ Statement } & Gender & \multicolumn{2}{|c|}{ Disagree } & \multicolumn{2}{|c|}{ Undecided } & \multicolumn{2}{|c|}{ Agree } \\
\hline & & Freq & $\%$ & Freq & $\%$ & Freq & $\%$ \\
\hline \multicolumn{8}{|l|}{ Confidence in Chemistry } \\
\hline \multirow[t]{2}{*}{ I am sure that I can learn chemistry. } & Male & 28 & 17.9 & 22 & 14.0 & 107 & 68.1 \\
\hline & Female & 74 & 57.4 & 19 & 14.7 & 36 & 27.9 \\
\hline \multirow[t]{2}{*}{ I am sure of myself when I do chemistry. } & Male & 28 & 17.8 & 8 & 5.1 & 121 & 77.1 \\
\hline & Female & 98 & 76.0 & 11 & 8.5 & 20 & 15.5 \\
\hline \multirow{2}{*}{$\begin{array}{l}\text { I think I can handle more difficult } \\
\text { chemistry questions. }\end{array}$} & Male & 40 & 25.5 & 9 & 5.7 & 108 & 68.8 \\
\hline & Female & 63 & 48.8 & 25 & 19.4 & 41 & 31.8 \\
\hline \multicolumn{8}{|l|}{$\begin{array}{lll}\begin{array}{l}\text { Perception } \\
\text { Teachers }\end{array} & \text { towards } & \text { chemistry } \\
\end{array}$} \\
\hline \multirow{2}{*}{$\begin{array}{l}\text { My teachers have been interested in my } \\
\text { progress in chemistry. }\end{array}$} & Male & 29 & 18.5 & 10 & 6.4 & 118 & 75.2 \\
\hline & Female & 19 & 14.7 & 2 & 1.6 & 108 & 83.7 \\
\hline
\end{tabular}




\begin{tabular}{|l|l|c|c|c|c|c|c|}
\hline & & & & & & & \\
\hline $\begin{array}{l}\text { My teachers have encouraged me to study } \\
\text { more chemistry. }\end{array}$ & Male & 29 & 18.5 & 37 & 23.6 & 91 & 58.0 \\
\cline { 2 - 8 } & Female & 26 & 20.2 & 3 & 2.3 & 100 & 77.5 \\
\hline $\begin{array}{l}\text { I would talk to my chemistry teacher } \\
\text { about a career that uses chemistry. }\end{array}$ & Male & 40 & 25.5 & 6 & 3.8 & 111 & 70.7 \\
\cline { 2 - 8 } Usefulness of Chemistry & Female & 26 & 20.2 & 15 & 11.6 & 88 & 68.2 \\
\hline $\begin{array}{l}\text { Knowing chemistry will help me earn a } \\
\text { living. }\end{array}$ & Male & 42 & 26.8 & 33 & 21.0 & 82 & 52.2 \\
\cline { 2 - 8 } & Female & 79 & 61.2 & 19 & 14.7 & 31 & 24.0 \\
\hline I will need chemistry for my future work. & Male & 52 & 33.1 & 5 & 3.2 & 100 & 63.7 \\
\cline { 2 - 8 } & Female & 74 & 57.4 & 2 & 1.6 & 53 & 41.1 \\
\hline $\begin{array}{l}\text { Chemistry is a worthwhile necessary } \\
\text { subject }\end{array}$ & Male & 25 & 15.9 & 12 & 7.6 & 120 & 76.4 \\
\cline { 2 - 8 } & Female & 78 & 60.5 & 4 & 3.1 & 47 & 36.4 \\
\hline
\end{tabular}

Table 1 shows that $107(68.1 \%)$ male students and 36(27.9\%) female students agreed with the statement that they were sure they can learn chemistry, 28(17.9\%) male and 74(57.4\%) female students disagreed with the statement and 22(14.0\%) male and 19(14.7\%) female students were undecided on the statement. The study findings showed that majority $(68.1 \%)$ of male students believed that they were sure of learning chemistry while a majority (57.4\%) of the female students was not sure of learning chemistry. This shows that male students were more confident of learning chemistry as compared to female students. The findings therefore point out that poor confidence among girls in learning chemistry contributes to their poor performance in the subject. This agrees with the findings of Ssempala (2005) who noted in that girls had poor self confidence in their ability to learn chemistry as most of them believed that boys were better in sciences.

In addition, 121(77.1\%) male and 20(15.5\%) female students agreed with the statement that they were sure of themselves when doing chemistry, 28(17.8\%) male and 98(76.0\%) female students disagreed with the statement while $8(5.1 \%)$ male and $11(8.5 \%)$ female students were undecided on the statement. From the responses, it emerged that majority $(77.1 \%)$ male students believed that they were sure of themselves when doing chemistry as compared to majority $(76.0 \%)$ of the females who believed that they were not sure of themselves when doing chemistry. This implies that girls lack self-confidence while undertaking chemistry problems. Studies have suggested that even many high-achieving girls have low levels of confidence in their ability to solve science and mathematics problems and express high levels of anxiety towards these subjects (Akporehwe \& Onwioduokit, 2010).

On the statement that "I think I can handle more difficult chemistry questions", 108(68.8\%) male and 41(31.8\%) female students agreed with the statement, $40(25.5 \%)$ male and 63(48.8\%) female students disagreed with the statement and 9(5.7\%) male and 25(19.4\%) female students were neutral on the statement. From the responses, it emerged that majority of the male students $(68.8 \%)$ believed that they could handle more difficult chemistry operations while most $(48.8 \%)$ of the female students believed that they were not able to handle more difficult questions. This therefore shows that male students had more confidence in handling difficult chemistry questions in comparison to their female counterparts. Thus, for this case it seems that female students have high anxiety when it comes to handling of chemistry questions in comparison to male students. This concur with the findings of Hyde et al.(1990)who found out that women reported greater levels of anxiety about mathematics than men.

In addition, 118(75.2\%) male and 108(83.7\%) female students agreed with the statement that their teachers were interested in their progress in chemistry, 29(18.5\%) male and 19(14.7\%) female students disagreed with the statement while $10(6.4 \%)$ male and 2(1.6\%) female students were undecided on the statement. The responses showed that majority of both male $(75.2 \%)$ and female students $(83.7 \%)$ believed that their teachers were interested in their progress thus showing a positive attitude towards their teachers. This points out that a positive attitude by both male and female students towards teachers will in turn lead to a better achievement in chemistry. This is consistent with the works of Sofiani et al., (2017) who noted that students' attitude towards science varies among the students, depends on factors that are associated with the teacher, such as teaching methods, classroom management, and teachers' knowledge of content and personality. 
Similarly, 91(58.0\%) male and 100(77.5\%) female students agreed with the statement that their teachers encouraged them to study more chemistry, 29(18.5\%) male and 26(20.2\%) female students disagreed with the statement while $37(23.6 \%)$ male and $3(2.3 \%)$ female students were undecided on the statement. From the responses, it emerged that majority of both male $(58.0 \%)$ and female $(77.5 \%)$ students believed that they were encouraged by their teachers to study more chemistry. This implies that female students had a more positive attitude towards the encouragement that was provided by their teachers.

In addition, $111(70.7 \%)$ male and $88(68.2 \%)$ female students agreed with the statement that they talked to their chemistry teachers concerning careers that apply chemistry, 40(25.5\%) male and 26(20.2\%) female students disagreed with the statement and 6(3.8\%) male and 15(11.6\%) female students were undecided on the statement. From the responses, it emerged that majority of both male111(70.7\%) and female 88(68.2\%) believed that they communicated with their teachers concerning careers that needed chemistry. This shows that male and female students had a positive attitude towards careers that had chemistry even though male students had a more positive attitude than the female students. One of the key factors in learning science is students' attitudes and the development of positive attitudes toward science can motivate student interest in science education and sciencerelated careers (George, 2006).

Further, 82(52.2\%) male and 31(24.0\%) female students agreed with the statement that knowing chemistry will help them earn a living, 42(26.8\%) male and 79(61.2\%) female students disagreed with the statement and 33(21.0\%) male and 19(14.7\%) female students were undecided on the statement. From the responses, it emerged that majority $82(52.2 \%)$ of male students believed that knowing chemistry would help them earn a living while majority $79(61.2 \%)$ female students believed otherwise showing that female students had a negative attitude towards the usefulness of chemistry. This concurs with a study by Majere, Role, \& Makewa (2016) on self-concept, attitude and perception of usefulness of physics and chemistry according to type and location of schools which found out that difference in perception of the usefulness of Chemistry was statistically significant between students in urban schools.

Further, 100(63.7\%) male and 53(41.1\%) female students agreed with the statement that they needed chemistry for their future work, 52(33.1\%) male and 74(57.4\%) female students disagreed with the statement and 5(3.2\%) male and $2(1.6 \%)$ female students were neutral on the statement. As shown by the responses, it emerged that majority $(63.7 \%)$ of the male students believed that they needed chemistry for their future work while majority $(57.4 \%)$ of the female students believed otherwise. This implies that female students had a more negative attitude towards importance of chemistry in their future work. This therefore shows that they tend not to make an effort to learn and understand the meaning of chemistry concepts that are being taught to them. It was shown that the most effective factor contributing to students' decisions to study science is their interest in the subject (Lindahl, 2003). Therefore, in this study, female students showed negative attitude towards importance of chemistry thus affecting their performance.

Similarly, 120(76.4\%) male and 47(36.4\%) female students agreed with the statement that chemistry is a worthwhile and necessary subject, 25(15.9\%) male and 78(60.5\%) female students disagreed with the statement and $12(7.6 \%)$ male and $4(3.1 \%)$ female students were undecided on the statement. The study findings showed that majority (76.4\%) of the male students believed that chemistry is a worthwhile and necessary subject while on the contrary, majority $(60.5 \%)$ of the female students in the study area believed otherwise. The study shows that male students are more positive on the importance of chemistry but the female students attach no significance to chemistry. This was found to concur with the findings of Barnes et al. (2005) in Australia which revealed that the attitudes of boys towards chemistry was more positive than were those of girls. This therefore shows that the negative attitude of girls towards the usefulness of chemistry plays a significant role in their performance.

In this study, independent sample t-test was performed to determine whether there was a significant difference between the means of male and female students on their attitude towards learning of chemistry. The results are presented in Table.2.

Table 2:-Difference in the means of male and female students on their attitude towards learning of chemistry

\begin{tabular}{|l|c|c|}
\hline & Levene's & t-test for Equality of Means \\
& Test for & \\
Equality of & \\
\hline
\end{tabular}




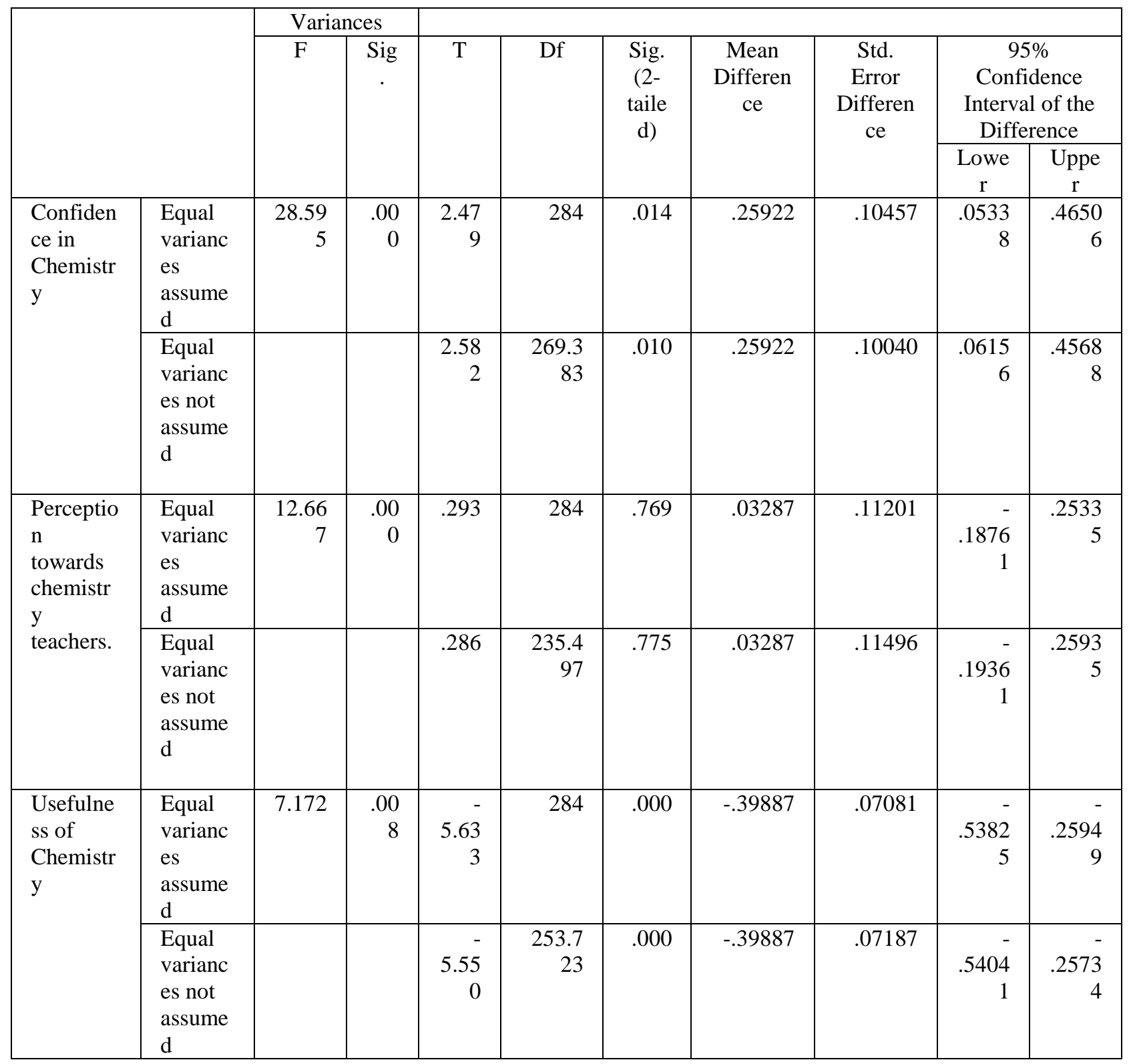

Table 2 points out that all the three variables under attitude on this study (Confidence in Chemistry, Perception towards chemistry teachers and Usefulness of Chemistry) were all significant $(\mathrm{p} \leq .05)$. In this study, students' Confidence in Chemistry had a p-value of .000 and students' Perception towards chemistry teachers had a p-value of .000 while students' perception towards usefulness of Chemistry had a p-value of Usefulness of Chemistry which indicates that the variances (for boys and girls) are significantly different. This shows that there was a significant difference between boys and girls in terms of attitude towards chemistry (Confidence in Chemistry, Perception towards chemistry teachers and Usefulness of Chemistry).

On interviewing teachers of chemistry, it emerged that in comparison to girls, there were more boys who enjoyed learning chemistry particularly in mixed secondary schools. However, in girl schools, there were girls who were very good in Chemistry and categorically wanted to further their careers in chemistry. In one of the girl schools, the chemistry teacher had this to say: 


\section{Teacher 5:}

In my class I have over ten girls who usually score A in chemistry and are determined to do courses related to chemistry in the university.

The sentiments show that despite majority of the girls having a negative attitude in chemistry as a subject, there are some bright girls who would want to take chemistry as a subject and are performing better than most boys in chemistry. This therefore shows that the negative attitude that is displayed by most girls towards chemistry is not a pointer that they cannot outperform their male counterparts.

Observation that was conducted pointed out that most of the girls were taking chemistry as a subject in comparison to other science subjects like physics. This was particularly noted in those schools where chemistry was an optional subject. However, in some schools, chemistry was considered to be an important subject therefore was made to be compulsory to be undertaken by all students.

\section{Conclusion and Recommendations:-}

The study concluded that there was a significant difference between boys and girls in terms of attitude towards chemistry (Confidence in Chemistry, Perception towards chemistry teachers and Usefulness of Chemistry). The negative perception towards chemistry negatively influenced girls' performance in the subject. The study recommended that the negative attitude displayed by most girls towards learning of chemistry affects negatively their performance. Therefore, teachers of chemistry need to encourage and motivate girls to develop a positive attitude toward the importance of chemistry as a subject.

\section{Significance of the Study}

The findings of this study could provide a framework for teachers on which they could re-evaluate their instructional strategies during Chemistry lessons for the enhancement of effective teaching and learning. In addition, it could provide insight for the curriculum designers into the kind of practical experiences in secondary school Chemistry needed to aid sound understanding of scientific concepts and principles. Further the study findings could provide a framework for the Kenya National Examination Council (KNEC) on which it could re-evaluate their goals and objectives so that the practices during secondary school Chemistry lessons especially practicals are in line with the curriculum demand of students.

\section{References:-}

1. Abudu, K.A. and Gbadamosi, M.R. (2014). Relationship between teacher's attitudes and student academic achievement in senior secondary school chemistry. A case study of Ijebu-Ode and Odgbolu Local Government area of Ogun State. Wudpecker Journal of Educational Research, 3(3):35-43.

2. Ajayi, K. O., Adewale, T. M., and Muraina, K. O. (2006). Enhancing the performance of Nigerian Senior Secondary School Students through good study habits. J. Applied Edu. Vocational Teclm. (JAEVR), 1(1), 1831.

3. Akporehwe, J. N. and Onwioduokit, F. A. (2010). Enhancing scientific attitudes through activity-based approaches. Nigerian Journal of Science and Science Education, vol. 8, no. 2.

4. Banye, S.K. (2005). Study of factors affecting attitudes of young female students toward chemistry at the high school level. Ph.D. dissertation. Collage of Science and Technology of the University of Southern Mississippi.

5. Barnes, G., McInerney, D. M. and Marsh, H. W. (2005). Exploring sex differences in science enrolment intentions: An application of the general model of academic choice. Australian Educational Researcher, 32(2), 1-23.

6. Chang, S.N, Yeung, Y, Y; and Cheng, M. H. (2009) Ninth graders' learning interests, life experiences and attitudes towards science \& technology. Journal of science education and technology, 18 (5), 447- 457.

7. Creswell, J. W. and Clark, V. L. (2011). Designing and conducting mixed methods research (2nd ed). Sage.

8. George, R. (2006). A cross-domain analysis of change in students' attitudes toward science and attitudes about the utility of science. International Journal of Science Education, 28: 571-589.

9. Glasman, L. R.and Albarracín, D. (2006). Forming attitudes that predict future behavior: a meta-analysis of the attitude-behavior relation. Psychol Bull.;132(5):778-822.

10. Hayden, M. C. and Thompson, J. (2005). Perceptions of students towards International Education: A preliminary Study. Journal of Education vol. 41, no. 5, pp. 389-404. 
11. Hyde, J. S., Fennema, E., Ryan, M., Frost, L. A. and Hopp, C. (1990). Gender comparisons of mathematics attitudes and affect: A meta-analysis. Psychol. Women Q. 14, 299.

12. Kalu, I. and Ali, A. N. (2004). Classroom interaction patterns, teacher and student characteristics and students' learning outcomes in physics. The Journal of Classroom Interaction, 24-31.

13. Kasomo, D. (2001). Research methods in humanities and education. Nairobi. Egerton University Press.

14. Kelly, A. (1988). Sex Stereotypes and School Science: a three-year follow-up. Educational Studies, 14: 2,151163.

15. Kelly, N. and Antonio, A. (2016). Teacher peer support in social network sites. Teaching and Teacher Education, 56, 138-149.

16. Kombo, D. K., and Tromp, D. L. (2009). Introduction to proposal writing. Nairobi: Pauline publications.

17. Krejcie, R.V. and Morgan, D.W. (1970). Determining sample size for research activities. Educational and Psychological measurement, No:30, pp.607-610).

18. Lindahl, B. (2003). Changing the subject to get more students to science and Technology. A paper presented at the GAST 11 conference, Mauritius,

19. Majere, I. S., Role, E. and Makewa, L. N. (2016). Self-concept, attitude and perception of usefulness of physics and chemistry according to type and location of schools. MIER Journal of Educational Studies, Trends and Practices, 3(2).

20. Mugenda, G.A. and Mugenda, O. (2003). Qualitative and Quantitative Approaches. Nairobi: Acts Press.

21. Murphy, P. and Whitelegg, E. (2006). Girls and physics: Continuing barriers to 'belonging'. The Curriculum Journal, 17(3), 281-305.

22. Osborne, J. \& Collins, S. (2001). Pupils' views of the role and value of the science curriculum: A focus group study. International Journal of Science Education, 23(5), 441-467.

23. Salta, K. and Tzougraki, C. (2003). Attitudes toward Chemistry among $11^{\text {th }}$ Grade students in high schools in Greece. Wiley Inter Science Journal 3(1)535-347

24. Sofiani, D., Maulida, A S., Fadhillah, N.and Sihite, D Y (2017). Gender Differences in Students' Attitude towards Science. International Conference on Mathematics and Science Education (ICMScE), 1-8.

25. Spall, K., Dickson, D.and Boyes, E. (2004). Development of school students' constructions of biology and physics. International Journal of Science Education, 26(7), 787-803.

26. Ssempala, F. (2005). Gender differences in the performance of Chemistry practical skills among senior six students in Kampala. Boston: Bola Baton.

27. Warrington, M. and Younger, M. (2000). The other side of the gender gap. Gender and Education, 12(4), 493-508. 